\title{
Advances in culture methods for acute myeloid leukemia research
}

\author{
Krishnapriya Syama ${ }^{1}$, Eman M. Hassan ${ }^{1}$ and Shan Zou ${ }^{1}$ \\ ${ }^{1}$ Metrology Research Centre, National Research Council Canada, Ottawa, Ontario, Canada
}

Correspondence to: Shan Zou, email: Shan.Zou@nrc-cnrc.gc.ca

Keywords: co-culture; 3D culture; CD47; calreticulin; cytokines

Received: April 09, $2021 \quad$ Accepted: July 28, $2021 \quad$ Published: August 04, 2021

Copyright: ( 2021 Syama et al. This is an open access article distributed under the terms of the Creative Commons Attribution License (CC BY 3.0), which permits unrestricted use, distribution, and reproduction in any medium, provided the original author and source are credited.

\section{ABSTRACT}

\begin{abstract}
Conventional suspension cultures have been used in Acute Myeloid Leukemia (AML) research to study its biology as well as to screen any drug molecules, since its inception. Co-culture models of AML cells and other stromal cells as well as 3 dimensional (3D) culture models have gained much attention recently. These culture models try to recapitulate the tumour microenvironment and are found to be more suitable than suspension cultures. Though animal models are being used, they require more time, effort and facilities and hence, it is essential to develop cell culture models for high-throughput screening of drugs. Here, we discuss a new co-culture model developed by our research group involving acute myeloid leukemia (AML) cells and stimulated macrophages. Other studies on co-culture systems and relevance of 3D culture in leukemic research in understanding the pathology and treatment of leukemia are also reviewed.
\end{abstract}

\section{INTRODUCTION}

Immune therapy has been a focus of research for past few decades $[1,2]$. There are various strategies to modulate the immune response - functional monoclonal antibodies as immune checkpoint inhibitors, cell based therapies such as chimeric antigen receptor (CAR)-T cell therapy, inhibition of immunosuppressive mechanisms and vaccines to improve antigen presentation [3-7]. These approaches are being used in the treatment of hematological malignancies [8,9]. Conventional 2D culture of leukemia cells involve only tumour cells in suspension and they are not in communication with other stromal cells or immune cells, unlike in a tumour microenvironment [10]. They also lack cell-extra cellular matrix (ECM) interactions [11]. Xenograft in vivo models are considered to be the gold standard in cancer research, however, it requires more time, effort and facilities and therefore more expensive [12, 13]. Hence, in vitro models need to be modified, which include the tumour-immune cell interactions.

In a tumour microenvironment, malignant cells are in contact with different types of cells like non-malignant stromal cells, macrophages and T lymphocytes [14-16]. They are continuously engaged in cytokine, chemokine and other growth factor signaling cascades, which helps in their proliferation, migration and invasion [17, 18]. Hence it is difficult to exactly recapitulate the in vivo tumour microenvironment in vitro. The difference in signaling mechanisms contributing for leukemic cell proliferation in both in vitro and in vivo models has been reviewed very recently [19]. These differences should be considered to develop more reliable in vitro models.

Co-culture models have been gaining much attention in cancer research due to their recapitulation of the tumour microenvironment. Co-culture models are broadly of 2 types: 1) Direct and 2) Indirect [20, 21]. In direct coculture, two types of cells, for example; tumour cells and stromal cells, are physically in contact with each other and communicate through paracrine signaling. However, in an indirect co-culture, tumour cells and stromal cells are cultured in separate compartments or conditioned medium of one cell type is supplied to the other cell type. This allows the sharing of biomolecules through a permeable membrane, which segregates the two types of cells [20, 22]. From our perspective, direct co-culture seems to be better as it mimics the conditions in an in vivo tumour. In a tumour microenvironment, cancer cells are surrounded by stromal cells and cancer-stromal cell interactions are crucial for tumorigenesis and metastasis. Direct co-culture 
would be satisfying the above in vivo conditions, hence it may be better than indirect co-culture models. Co-culture models with tumour cells and stromal cells are considered to be better to evaluate therapeutic drugs like monoclonal antibodies, small molecule inhibitors and nano-drug carriers [23]. Some of the highlights and complications of these co-culture approaches are summarized in Table 1.

\section{Co-culture model with AML cells and macrophages}

Our research group has recently demonstrated the use of a co-culture model with Acute Myeloid Leukemia (AML) cells and stimulated macrophages in vitro [24]. This study demonstrated that AML cells, when in coculture with stimulated macrophages, were eliminated and their expression of the "don't eat me signal", CD47 [25-28] was down-regulated.

This study showed that CD47 inhibition was successful and selective in AML but not normal cells [24]. Expression levels of another protein, Calreticulin (CRT), "eat me signal" were up-regulated in the AML cells cocultured with stimulated macrophages. Interestingly, significant down-regulation of CD47 and up-regulation of CRT expression was observed in AML cells, only when they are co-cultured with stimulated macrophages and not under any other culture conditions. Activated macrophages were shown to secrete high levels of cytokines such as IL-12p70, IL-6 and TNF- $\alpha$. This co-culture model can be used to screen the efficacy of new drugs in AML treatment. It also demonstrates the possibility of using human macrophages for the treatment of AML [24]. There are only a few reports focusing on restoring immune surveillance in AML cells. Some of the studies were either focused on inhibition of CD47 or on up-regulation of CRT [29-31]. The co-culture model developed by our group, demonstrated that stimulated macrophages help both phenomenon to occur simultaneously [24].

Various strategies have been used to target CD47, as it serves as the "don't eat me signal", and inhibit phagocytosis by macrophages, thereby reducing the immune surveillance. Immunotherapy targeting CD47-SIRP- $\alpha$ are under clinical investigation, mainly monoclonal antibodies [32-34]. One of the monoclonal antibodies, 5F9, has been showing promising results in a phase $1 \mathrm{~b}$ clinical trial and currently, Hu5F9/magrolimab combined with azacitidine (placebo as control) is in phase III trial [35]. Small molecule inhibitors and tyrosine kinase inhibitors were shown to target CD47-SIRP- $\alpha$ signaling in leukemia, lymphoma and melanoma cells $[36,37]$. Other molecules such as Pep20, D4-2, RRx-001, metformin were reported to block this signaling axis in colon carcinoma, lymphoma, melanoma, non-small cell lung cancer and breast cancer [37]. The co-culture model developed with AML cells and macrophages is a good platform to test these monoclonal antibodies (mAbs) and small molecule inhibitors. By adding different concentrations of mAbs or small molecule inhibitors to the tumour cells in co-culture with macrophages, the expression of CD47 and CRT can be evaluated by flow cytometry. We can also evaluate if these drugs promotes the elimination of tumour cells by apoptosis or viability assays such as Alamar blue assays. The synergistic effect of stimulated macrophages and the drug molecules can be evaluated using this coculture model. The successful co-culture studies could be extended to in vivo mouse models.

\section{Drug screening using two dimensional (2D) co- culture models of leukemia}

Co-culture studies with leukemic cells and stromal cells or immune cells led to the identification of many drug targets [38]. The first study to report the co-culture of leukemia cells and bone marrow derived stromal cells demonstrated that purified chronic lymphocytic leukemia (CLL) cells grown on stromal cells had a prolonged survival $[38,39]$. It was also demonstrated that CLL marrow stromal cell co-culture offer a more reliable and relevant model to study the marrow stromal cell - CLL cell interactions, when compared to suspension cultures [40]. In another report, HS-5 stromal cells were pre-treated with anti-cancer drugs like Ara-C, doxorubicin, daunorubicin and then, co-cultured with K562 cells. In co-culture, K562 cells proliferated rapidly and hence, it can be inferred that leukemia patients when undergoing chemotherapy have deficient stromal cells resulting in a cytokine-deficient microenvironment. These aspects should be considered during chemotherapeutic failure [41].

Another preclinical study demonstrated the potential of CD4CAR-expressing T cells in eliminating malignant CD4+ cells. It was shown that CD4-specific chimeric antigen receptor (CAR)-engineered $\mathrm{T}$ cells (CD4CAR T cells), when in co-culture with CD4+ T cell leukemic cell lines (KARPAS 299 cells, primary leukemia cells from a patient), eliminated CD4+ T leukemic cells [42]. Another report showed that on co-culture with bone marrow stromal cells, MS-5 (pre-treated with chemo drugs like ARA, doxorubicin, etoposide or vincristine), AML cells showed an increase of mitochondrial content by $14 \%$ and resulted in a higher survival of leukemic blasts and leukemia initiating cells [43].

THP-1 cells were known to supress $\mathrm{T}$ cells and this suppressive ability of THP-1 cells was reversed by blocking LILRB4 signaling by monoclonal antibody, h128-3. This has been elucidated by a co-culture model of THP-1 cells and T cells. In addition to this, co-culture of peripheral blood mononuclear cells (PBMCs) and THP-1 cells in presence of h128-3, led to the increased secretion of cytokines such as IL2, IL7, CXCL9 and CXCL11, which help in the proliferation and activation of T cells [44]. LILRB4, is an immunoreceptor tyrosinebased inhibition motif containing receptor and a marker 
Table 1: 2D and 3D co-culture methods for the leukemia research

\begin{tabular}{|c|c|c|c|c|c|}
\hline Method & & Analysis Type & Highlights & Complications & Examples \\
\hline 2D culture & & $\begin{array}{l}\text { Cells are grown as } \\
\text { suspension cells }\end{array}$ & $\begin{array}{l}\text { Easy and cheap compared } \\
\text { to } 3 \mathrm{D} \text { culture methods }\end{array}$ & $\begin{array}{l}\text { Lack cell-cell junctions, } \\
\text { sensitive to all drugs, gene } \\
\text { and protein expression levels } \\
\text { are different to that of in vivo } \\
\text { tumours }\end{array}$ & AML $[77,78]$ \\
\hline 3D culture & & $\begin{array}{l}\text { Cells are grown as } \\
\text { spherical-like structures on } \\
\text { different matrices/scaffolds } \\
\text { and have multiple layers }\end{array}$ & $\begin{array}{l}\text { Close to the in vivo tumour } \\
\text { microenvironment, and } \\
\text { cells are resistant to drugs } \\
\text { and hence physiologically } \\
\text { relevant } \\
\text { Cell-extra cellular } \\
\text { matrix interactions can } \\
\text { be studied }\end{array}$ & $\begin{array}{l}\text { Expensive } \\
\text { Time consuming } \\
\text { Needs optimization }\end{array}$ & AML $[61,79,80]$ \\
\hline \multirow{3}{*}{ Co-culture } & $\begin{array}{l}\text { Direct } \\
\text { co-culture }\end{array}$ & $\begin{array}{l}\text { Two types of cells - } \\
\text { Tumour and stromal; } \\
\text { Both tumour and stromal } \\
\text { cells are physically in } \\
\text { contact with each other }\end{array}$ & $\begin{array}{l}\text { Can study the effect of } \\
\text { stromal cells on tumour } \\
\text { cells and vice-versa }\end{array}$ & $\begin{array}{l}\text { Unable to do downstream } \\
\text { assays separately for each } \\
\text { type of cell }\end{array}$ & $\begin{array}{l}\text { AML and mesenchymal } \\
\text { stromal cells [81] } \\
\text { Mesenchymal stem and } \\
\text { AML cells [61] }\end{array}$ \\
\hline & $\begin{array}{l}\text { Indirect } \\
\text { co-culture }\end{array}$ & $\begin{array}{l}\text { In separate compartments; } \\
\text { Medium from one cell type } \\
\text { is supplied to the other cell } \\
\text { type }\end{array}$ & $\begin{array}{l}\text { Sharing of biomolecules } \\
\text { through a permeable } \\
\text { membrane } \\
\text { Better evaluate } \\
\text { therapeutic drugs than } \\
\text { a } 2 \mathrm{D} \text { culture }\end{array}$ & $\begin{array}{l}\text { Permeable membrane inserts } \\
\text { are expensive and these } \\
\text { models do not exactly mimic } \\
\text { the conditions in a tumour } \\
\text { microenvironment }\end{array}$ & $\begin{array}{l}\text { AML cells and } \\
\text { macrophages [24] }\end{array}$ \\
\hline & 3D co-culture & $\begin{array}{l}\text { Leukemia cells are grown } \\
\text { as } 3 \mathrm{D} \text { structures and grown } \\
\text { with stromal/immune cells }\end{array}$ & $\begin{array}{l}\text { Mimic more closely } \\
\text { the histologic conditions } \\
\text { compared to } 2 \mathrm{D} \text { co-culture } \\
\text { It can be an intermediate } \\
\text { platform between } 2 \mathrm{D} \text { and } \\
\text { xenografts }\end{array}$ & $\begin{array}{l}\text { Expensive and need to } \\
\text { optimize the matrices/ } \\
\text { scaffolds for both tumour and } \\
\text { stromal cells }\end{array}$ & $\begin{array}{l}\text { AML and bone marrow } \\
\text { mononuclear cells [79] } \\
\text { Human bone marrow } \\
\text { mesenchymal stem and } \\
\text { AML cells [61] }\end{array}$ \\
\hline
\end{tabular}

of monocytic leukemia. It has been shown by co-culture studies with AML cells and T cells that blocking or deletion of LILRB4 signaling inhibited AML growth. LILRB4 helps in tumour cell invasion of AML with the help of an immunosuppressive microenvironment and therefore, it is a powerful target for AML treatment [45].

A protocol was developed by co-culturing $\mathrm{T}$ cells and drug treated GFP-labeled AML suspension cells. The effect of drugs (targeting Fat mass and obesity-associated protein (FTO), which is an oncogene) were studied by flow cytometry using absolute counting beads. This co-culture assay allows us to test the effects of various drug combinations and study the innate mechanisms, which influence the immune response. Moreover, it could also help in understanding the combined effect of immunotherapy and chemotherapy [46]. The same research group reported that AML cells when pre-treated with FTO inhibitors, CS1 or CS2 and co-cultured with activated $\mathrm{T}$ cells, resulted in the increased killing of AML cells along with decreased expression of LILRB4 [47]. Acute myeloid leukemia initiating cells (LICs) are known to be responsible for the initiation and relapse of AML. It has been reported that LICs can be maintained around
3 weeks, by modeling the tumour niche, using stromal feeder layers and hypoxic conditions. This model offers a reliable, easy, and reproducible niche-based culture system suitable to study chemoresistance of LICs and to screen new therapeutic drugs specifically against LICs [48].

\section{Significance of $3 D$ culture and $3 D$ co-culture models}

Although 2D co-culture models are being used in research, 3D models are much more appropriate and are close to the in vivo tumour microenvironment [38]. Tumour-stromal cell interactions play a major role in tumour development and progression. Stromal cells such as endothelial cells and immunocompetent cells contribute to tumour angiogenesis and invasion [49]. It is important to recapitulate the tumour microenvironment in vitro to study the biology of tumour as well as to screen various therapeutic drug molecules. This is why researchers have developed 3D culture of cancer cells and they are an excellent model compared to the conventional monolayer culture of tumour cell lines [50-52]. 
Molecular mechanisms of leukemogenesis have been elucidated to a certain extent with the help of 2D culture and animal models. However, the cellular and microenvironmental components, which help in leukemia cell proliferation and resistance of leukemic stem cells from conventional chemo-radiation therapies, are still difficult to be studied $[53,54]$. Three major challenges to study AML are 1) current $2 \mathrm{D}$ culture requires growth factors and stromal cells, for the prolonged survival of tumour cells 2) 2D culture cannot offer the natural haematopoietic microenvironment, which is also responsible for the drug resistance of leukemic stem cells and 3) in vivo animal models are not exactly like the human tumour microenvironment and are expensive and time consuming. Hence, development of an ex vivo 3D model could mimic the tumour microenvironment to study AML [55-57].

Three dimensional cell culture offers several advantages over conventional 2D culture [58, 59]. The alterations in cell morphology and their adaptive responses, expression of genes and metabolism are similar to that of in vivo tumour microenvironment [60]. Cells in 3D culture are more resistant to drugs and therefore, they are physiologically relevant and can better show the drug effects [61, 62]. The cells in the inside core of the tumour are in hypoxic conditions and this holds true with 3D cell culture as well [63]. In 2D culture, proliferation rates, gene and protein expression levels are different from that of the original tumour [64] whereas they are similar to the in vivo tumours in $3 \mathrm{D}$ culture models $[60,65]$. Hence, 3D models would be ideal to study various attributes of tumour such as angiogenesis, metastasis, and invasion, and also in identification of specific biomarkers and screening of drug targets $[52,66]$. A schematic of direct $3 \mathrm{D}$ co-culture model with AML cells and stromal cells is illustrated in Figure 1 and highlighted in Table 1.
In order to mimic the histological conditions of a tumour tissue, it is necessary to simultaneously grow tumour and stromal cells with cell-cell interactions and signaling cascades through various growth factors [67]. The presence of an extracellular matrix and interstitial fluid with essential nutrients and growth supplements are required for differentiation and maturation [60, 68, 69]. Three dimensional co-culture models with tumour cells and other stromal cells fulfill these requirements and hence are suitable preclinical tumour models $[70,71]$. There are reports on $3 \mathrm{D}$ co-culture models to be more efficient to screen drugs. Schematics of indirect 3D co-culture models are illustrated in Figure 2.

\section{Methods for 3D culture}

Broadly, the 3D culture can be divided into two types - 1) Anchorage independent (scaffold free) and 2) Anchorage dependent (scaffold based) [72].

Anchorage independent cultures include methods like hanging drop, ultra-low attachment plate and magnetic levitation. Cells are seeded as small droplets in specialized plates with open, bottom-less wells. Cells in the droplet aggregate and form spherical - like structures. They can be transferred to scaffold or ECM for further prolonged culture [73]. Ultra-low attachment plates are designed such that cells do not attach on their surface and they tend to form aggregates [74]. Magnetic levitation is the technique by which cells are preloaded with magnetic nanoparticles and in the presence of an external magnetic field, cells are floated toward air/liquid interface, thereby cell-cell aggregation occurs to form spherical-like structures [72] .

Anchorage dependent culture mainly includes scaffold-based culture systems. It can be of physical

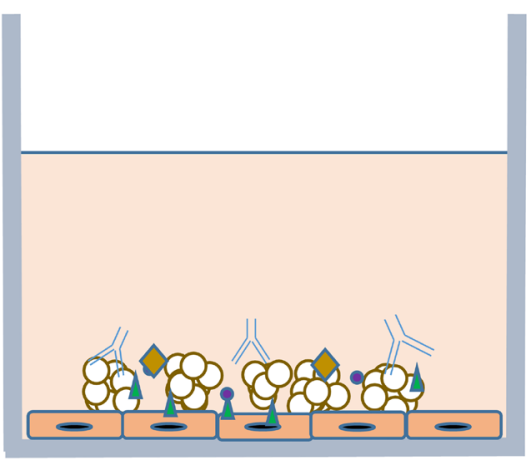

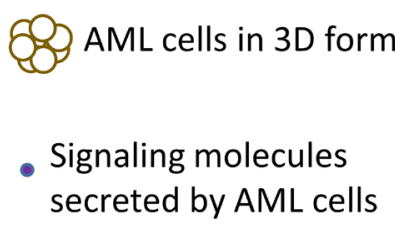

Stromal cells

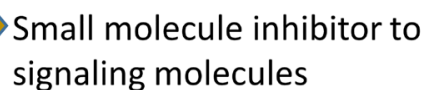

\section{$\triangle$ Signaling molecules secreted by stromal cells \\ Monoclonal antibody to tumour specific markers}

Figure 1: Schematic of a direct 3 Dimensional (3D) co-culture model of acute myeloid leukemia (AML) cells and stromal cells. Small molecule inhibitors or functional monoclonal antibodies targeting tumour specific molecule can be tested for their efficacy using this culture model. 
support, ranging from simple mechanical structures to ECM-like matrices. Cells can aggregate, proliferate and migrate on these matrices. Cells would be embedded in the matrix so that they are physically and chemically interacting with the scaffold material. Scaffold can be of synthetic (polyethylene glycol (PEG), polylactic acid (PA) and polyglycolic acid (PGA) or biological origin (alginate and matrigel) $[72,75]$.

\section{Challenges in 3D culture}

Although 3D culture mimics the in vivo tumour conditions, they are quite expensive and time consuming than 2D culture. They are more complex structures and hence downstream applications on these spheroids would need more optimization. Extracting cells from the 3D culture is difficult and sometimes it may change their morphology and original characteristics.

Sometimes, the matrices used in 3D culture would influence the behavior of the cells in 3D culture. It is still challenging to find a matrix or scaffold which exactly matches to that of the in vivo tumours. Due to these reasons, it remains challenging to use this model for prescreening drugs in clinical use.

\section{FUTURE PERSPECTIVES}

Tumour-stromal cell interaction can be studied using $3 \mathrm{D}$ co-culture models and these findings can be verified in clinical specimens. Three dimensional culture models in both solid tumours and hematological malignancies, have been a fascinating area of cancer research for more than two decades now and helped in improving our knowledge about the biology of tumours [70].

Some of the current limitations of 2D culture could be overcome by $3 \mathrm{D}$ culture and hence novel in vitro leukemic models need to be developed. The 3D tumour microenvironment includes different types of cell-cell interactions, cell-extracellular matrix interactions and these factors should be taken into consideration while developing new models [19]. The main objective is to develop a standardized culture model for in vitro studies to study the biology of the tumour as well as to test newly developed drug molecules [19]. A recent study reported the use of 3D ex vivo culture of CLL cells and showed a substantial increase in proliferative response compared to 2D suspension cultures [76]. This suggests that 3D culture models are more valuable and have more relevance to pathophysiological conditions.

A

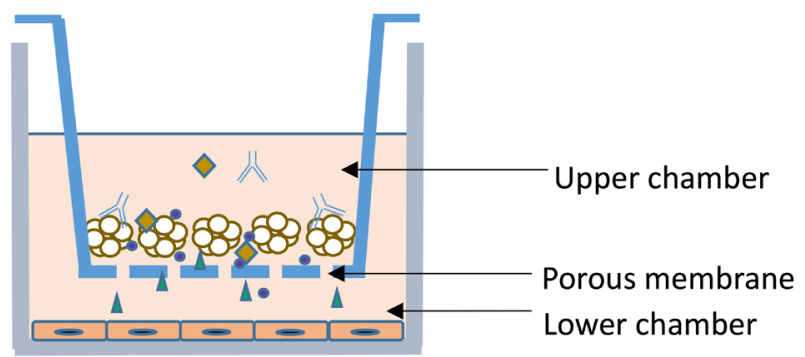

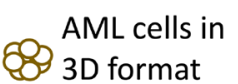

Signaling molecules secreted by AML cells

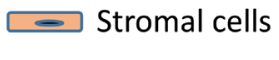

Small molecule inhibitor
to signaling molecules
Signaling molecules

\ secreted by stromal cells

Monoclonal antibody to tumour specific markers

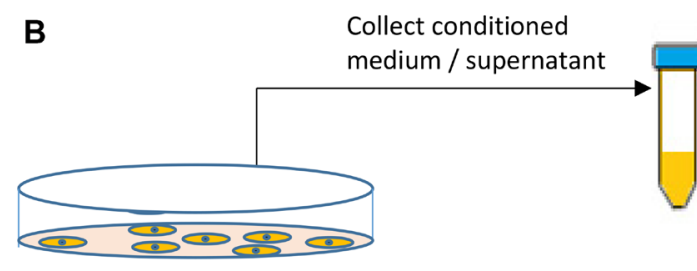

Stromal cells /

immune cells in 2D culture

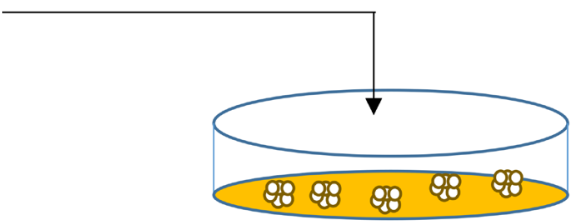

Culture AML cells in 3D conditions with conditioned medium

Figure 2: Schematic of two types of indirect 3 Dimensional (3D) co-culture model of acute myeloid leukemia (AML) cells and stromal cells. (A) A transmembrane separates the two types of cells and can be collected separately from each compartment and the assays can be done for each type of cells. (B) This model can be used for testing different drugs on AML (3D) cells and also the 3D cells can be recovered after the culture. There will be no contamination of stromal/immune cells which is helpful for further down-stream applications. 
The significance and necessity of co-culture models and $3 \mathrm{D}$ co-culture models is very obvious and this area of research needs to be more investigated. Developing ex vivo models, which closely mimic the in vivo tumour microenvironment should be the major focus. Three dimensional co-culture models with leukemic cells and stromal or immune cells would help to understand the pathogenesis. These models could be relevant in screening various drug targets as well as studying the leukemia initiating cells, which are responsible for the emergence and chemo-resistance of the tumour. Thus, 3D co-culture models could be used as the initial template to screen any drug prior to testing them in an in vivo model.

\section{CONFLICTS OF INTEREST}

Authors have no conflicts of interest to declare.

\section{REFERENCES}

1. Chhabra N, Kennedy J. A Review of Cancer Immunotherapy Toxicity II: Adoptive Cellular Therapies, Kinase Inhibitors, Monoclonal Antibodies, and Oncolytic Viruses. J Med Toxicol. 2021. https://doi.org/10.1007/s13181-021-008356. PMID:33821435

2. Kennedy LB, Salama AKS. A review of cancer immunotherapy toxicity. CA Cancer J Clin. 2020; 70:86104. https://doi.org/10.3322/caac.21596. PMID:31944278

3. Khalil DN, Smith EL, Brentjens RJ, Wolchok JD. The future of cancer treatment: immunomodulation, CARs and combination immunotherapy. Nat Rev Clin Oncol. 2016; 13:273-90. $\quad$ https://doi.org/10.1038/nrclinonc.2016.25. PMID:26977780

4. Koo SL, Wang WW, Toh HC. Cancer Immunotherapy - The Target is Precisely on The Cancer and Also Not. Ann Acad Med Singap. 2018; 47:381-87. PMID:30324966

5. Sambi M, Bagheri L, Szewczuk MR. Current Challenges in Cancer Immunotherapy: Multimodal Approaches to Improve Efficacy and Patient Response Rates. J Oncol. 2019; 2019:4508794. https://doi. org/10.1155/2019/4508794. PMID:30941175

6. Topalian SL, Weiner GJ, Pardoll DM. Cancer immunotherapy comes of age. J Clin Oncol. 2011; 29:4828-36. https://doi.org/10.1200/JCO.2011.38.0899. PMID:22042955

7. Yap TA, Parkes EE, Peng W, Moyers JT, Curran MA, Tawbi HA. Development of Immunotherapy Combination Strategies in Cancer. Cancer Discov. 2021. https://doi. org/10.1158/2159-8290.CD-20-1209. PMID:33811048

8. Noh JY, Seo H, Lee J, Jung H. Immunotherapy in Hematologic Malignancies: Emerging Therapies and Novel Approaches. Int J Mol Sci. 2020; 21:8000. https:// doi.org/10.3390/ijms21218000. PMID:33121189

9. Vasekar M, Rizvi S, Liu X, Vrana KE, Zheng H. Novel Immunotherapies for Hematological Malignancies. Curr
Mol Pharmacol. 2016; 9:264-71. https://doi.org/10.2174/1 874467208666150716121253. PMID:26177640

10. Rodrigues J, Heinrich MA, Teixeira LM, Prakash J. 3D In Vitro Model (R)evolution: Unveiling Tumor-Stroma Interactions. Trends Cancer. 2021; 7:249-64. https://doi. org/10.1016/j.trecan.2020.10.009. PMID:33218948

11. Colombo E, Cattaneo MG. Multicellular 3D Models to Study Tumour-Stroma Interactions. Int J Mol Sci. 2021; 22:1633. https://doi.org/10.3390/ijms22041633. PMID:33562840

12. Kelland LR. Of mice and men: values and liabilities of the athymic nude mouse model in anticancer drug development. Eur J Cancer. 2004; 40:827-36. https://doi.org/10.1016/j. ejca.2003.11.028. PMID:15120038

13. Sharpless NE, Depinho RA. The mighty mouse: genetically engineered mouse models in cancer drug development. Nat Rev Drug Discov. 2006; 5:741-54. https://doi.org/10.1038/ nrd2110. PMID:16915232

14. Bissell MJ, Radisky D. Putting tumours in context. Nat Rev Cancer. 2001; 1:46-54. https://doi.org/10.1038/35094059. PMID:11900251

15. Chen F, Zhuang X, Lin L, Yu P, Wang Y, Shi Y, Hu G, Sun Y. New horizons in tumor microenvironment biology: challenges and opportunities. BMC Med. 2015; 13:45. https://doi.org/10.1186/s12916-015-0278-7. PMID:25857315

16. Cheng YQ, Wang SB, Liu JH, Jin L, Liu Y, Li CY, Su YR, Liu YR, Sang X, Wan Q, Liu C, Yang L, Wang ZC. Modifying the tumour microenvironment and reverting tumour cells: New strategies for treating malignant tumours. Cell Prolif. 2020; 53:e12865. https://doi.org/10.1111/ cpr.12865. PMID:32588948

17. Choi MY, Kashyap MK, Kumar D. The chronic lymphocytic leukemia microenvironment: Beyond the B-cell receptor. Best Pract Res Clin Haematol. 2016; 29:40-53. https://doi. org/10.1016/j.beha.2016.08.007. PMID:27742071

18. Nagarsheth N, Wicha MS, Zou W. Chemokines in the cancer microenvironment and their relevance in cancer immunotherapy. Nat Rev Immunol. 2017; 17:559-72. https://doi.org/10.1038/nri.2017.49. PMID:28555670

19. Haselager MV, Kater AP, Eldering E. Proliferative Signals in Chronic Lymphocytic Leukemia; What Are We Missing? Front Oncol. 2020; 10:592205. https://doi.org/10.3389/ fonc.2020.592205. PMID:33134182

20. Kook YM, Jeong Y, Lee K, Koh WG. Design of biomimetic cellular scaffolds for co-culture system and their application. J Tissue Eng. 2017; 8:2041731417724640. https://doi. org/10.1177/2041731417724640. PMID:29081966

21. Regier MC, Alarid ET, Beebe DJ. Progress towards understanding heterotypic interactions in multi-culture models of breast cancer. Integr Biol. 2016; 8:684-92. https://doi.org/10.1039/c6ib00001k. PMID:27097801

22. Bogdanowicz DR, Lu HH. Studying cell-cell communication in co-culture. Biotechnol J. 2013; 8:395-96. https://doi.org/10.1002/biot.201300054. PMID:23554248 
23. Costa EC, Gaspar VM, Marques JG, Coutinho P, Correia IJ. Evaluation of nanoparticle uptake in co-culture cancer models. PLoS One. 2013; 8:e70072. https://doi.org/10.1371/ journal.pone.0070072. PMID:23922909

24. Hassan EM, Walker GC, Wang C, Zou S. Anti-leukemia effect associated with down-regulated CD47 and upregulated calreticulin by stimulated macrophages in coculture. Cancer Immunol Immunother. 2021; 70:787801. https://doi.org/10.1007/s00262-020-02728-z. PMID:32995942

25. Barclay AN, Brown MH. The SIRP family of receptors and immune regulation. Nat Rev Immunol. 2006; 6:457-64. https://doi.org/10.1038/nri1859. PMID:16691243

26. Blazar BR, Lindberg FP, Ingulli E, Panoskaltsis-Mortari A, Oldenborg PA, Iizuka K, Yokoyama WM, Taylor PA. CD47 (integrin-associated protein) engagement of dendritic cell and macrophage counterreceptors is required to prevent the clearance of donor lymphohematopoietic cells. J Exp Med. 2001; 194:541-49. https://doi.org/10.1084/jem.194.4.541. PMID:11514609

27. Matlung HL, Szilagyi K, Barclay NA, van den Berg TK. The CD47-SIRPalpha signaling axis as an innate immune checkpoint in cancer. Immunol Rev. 2017; 276:145-64. https://doi.org/10.1111/imr.12527. PMID:28258703

28. Subramanian S, Boder ET, Discher DE. Phylogenetic divergence of CD47 interactions with human signal regulatory protein alpha reveals locus of species specificity. Implications for the binding site. J Biol Chem. 2007; 282:1805-18. https://doi.org/10.1074/jbc.M603923200. PMID:17098740

29. Chao MP, Alizadeh AA, Tang C, Myklebust JH, Varghese B, Gill S, Jan M, Cha AC, Chan CK, Tan BT, Park CY, Zhao F, Kohrt HE, et al. Anti-CD47 antibody synergizes with rituximab to promote phagocytosis and eradicate nonHodgkin lymphoma. Cell. 2010; 142:699-713. https://doi. org/10.1016/j.cell.2010.07.044. PMID:20813259

30. Kauder SE, Kuo TC, Harrabi O, Chen A, Sangalang E, Doyle L, Rocha SS, Bollini S, Han B, Sim J, Pons J, Wan HI. ALX148 blocks CD47 and enhances innate and adaptive antitumor immunity with a favorable safety profile. PLoS One. 2018; 13:e0201832. https://doi.org/10.1371/journal. pone.0201832. PMID:30133535

31. Manna PP, Frazier WA. CD47 mediates killing of breast tumor cells via Gi-dependent inhibition of protein kinase A. Cancer Res. 2004; 64:1026-36. https://doi. org/10.1158/0008-5472.can-03-1708. PMID:14871834

32. Liu J, Wang L, Zhao F, Tseng S, Narayanan C, Shura L, Willingham S, Howard M, Prohaska S, Volkmer J, Chao M, Weissman IL, Majeti R. Pre-Clinical Development of a Humanized Anti-CD47 Antibody with Anti-Cancer Therapeutic Potential. PLoS One. 2015; 10:e137345. https://doi.org/10.1371/journal.pone.0137345. PMID:26390038

33. Pietsch EC, Dong J, Cardoso R, Zhang X, Chin D, Hawkins R, Dinh T, Zhou M, Strake B, Feng PH, Rocca M, Santos
CD, Shan X, et al. Anti-leukemic activity and tolerability of anti-human CD47 monoclonal antibodies. Blood Cancer J. 2017; 7:e536. https://doi.org/10.1038/bcj.2017.7. PMID:28234345

34. Sikic BI, Lakhani N, Patnaik A, Shah SA, Chandana SR, Rasco D, Colevas AD, O'Rourke T, Narayanan S, Papadopoulos K, Fisher GA, Villalobos V, Prohaska SS, et al. First-in-Human, First-in-Class Phase I Trial of the AntiCD47 Antibody Hu5F9-G4 in Patients With Advanced Cancers. J Clin Oncol. 2019; 37:946-53. https://doi. org/10.1200/JCO.18.02018. PMID:30811285

35. Advani R, Flinn I, Popplewell L, Forero A, Bartlett NL, Ghosh N, Kline J, Roschewski M, LaCasce A, Collins GP, Tran T, Lynn J, Chen JY, et al. CD47 Blockade by Hu5F9-G4 and Rituximab in Non-Hodgkin's Lymphoma. N Engl J Med. 2018; 379:1711-21. https://doi.org/10.1056/ NEJMoa1807315. PMID:30380386

36. Burgess TL, Amason JD, Rubin JS, Duveau DY, Lamy L, Roberts DD, Farrell CL, Inglese J, Thomas CJ, Miller TW. A homogeneous SIRPalpha-CD47 cell-based, ligand-binding assay: Utility for small molecule drug development in immuno-oncology. PLoS One. 2020; 15:e0226661. https:// doi.org/10.1371/journal.pone.0226661. PMID:32240171

37. Yu WB, Ye ZH, Chen X, Shi JJ, Lu JJ. The development of small-molecule inhibitors targeting CD47. Drug Discov Today. 2021; 26:561-68. https://doi.org/10.1016/j. drudis.2020.11.003. PMID:33197622

38. Scielzo C, Ghia P. Modeling the Leukemia Microenviroment In Vitro. Front Oncol. 2020; 10:607608. https://doi. org/10.3389/fonc.2020.607608. PMID:33392097

39. Panayiotidis P, Jones D, Ganeshaguru K, Foroni L, Hoffbrand AV. Human bone marrow stromal cells prevent apoptosis and support the survival of chronic lymphocytic leukaemia cells in vitro. Br J Haematol. 1996; 92:97103. https://doi.org/10.1046/j.1365-2141.1996.00305.x. PMID:8562418

40. Kurtova AV, Balakrishnan K, Chen R, Ding W, Schnabl S, Quiroga MP, Sivina M, Wierda WG, Estrov Z, Keating MJ, Shehata M, Jager U, Gandhi V, et al. Diverse marrow stromal cells protect CLL cells from spontaneous and drug-induced apoptosis: development of a reliable and reproducible system to assess stromal cell adhesionmediated drug resistance. Blood. 2009; 114:4441-50. https:// doi.org/10.1182/blood-2009-07-233718. PMID:19762485

41. Lee YC, Chiou TJ, Tzeng WF, Chu ST. Macrophage inflammatory protein-3alpha influences growth of K562 leukemia cells in co-culture with anticancer drug-pretreated HS-5 stromal cells. Toxicology. 2008; 249:116-22. https:// doi.org/10.1016/j.tox.2008.04.017. PMID:18538911

42. Pinz K, Liu H, Golightly M, Jares A, Lan F, Zieve GW, Hagag N, Schuster M, Firor AE, Jiang X, Ma Y. Preclinical targeting of human T-cell malignancies using CD4-specific chimeric antigen receptor (CAR)-engineered $\mathrm{T}$ cells. Leukemia. 2016; 30:701-07. https://doi.org/10.1038/ leu.2015.311. PMID:26526988 
43. Moschoi R, Imbert V, Nebout M, Chiche J, Mary D, Prebet T, Saland E, Castellano R, Pouyet L, Collette Y, Vey N, Chabannon C, Recher C, et al. Protective mitochondrial transfer from bone marrow stromal cells to acute myeloid leukemic cells during chemotherapy. Blood. 2016; 128:253-64. https://doi.org/10.1182/ blood-2015-07-655860. PMID:27257182

44. Gui X, Deng M, Song H, Chen Y, Xie J, Li Z, He L, Huang F, Xu Y, Anami Y, Yu H, Yu C, Li L, et al. Disrupting LILRB4/ APOE Interaction by an Efficacious Humanized Antibody Reverses T-cell Suppression and Blocks AML Development. Cancer Immunol Res. 2019; 7:1244-57. https://doi. org/10.1158/2326-6066.CIR-19-0036. PMID:31213474

45. Deng M, Gui X, Kim J, Xie L, Chen W, Li Z, He L, Chen Y, Chen H, Luo W, Lu Z, Xie J, Churchill H, et al. LILRB4 signalling in leukaemia cells mediates $\mathrm{T}$ cell suppression and tumour infiltration. Nature. 2018; 562:605-09. https:// doi.org/10.1038/s41586-018-0615-z. PMID:30333625

46. Li Y, Su R, Chen J. Co-culture Systems of Drug-Treated Acute Myeloid Leukemia Cells and T Cells for In Vitro and In Vivo Study. STAR Protoc. 2020; 1:100097. https://doi. org/10.1016/j.xpro.2020.100097. PMID:32995754

47. Su R, Dong L, Li Y, Gao M, Han L, Wunderlich M, Deng X, Li H, Huang Y, Gao L, Li C, Zhao Z, Robinson $\mathrm{S}$, et al. Targeting FTO Suppresses Cancer Stem Cell Maintenance and Immune Evasion. Cancer Cell. 2020; 38:79-96.e11. https://doi.org/10.1016/j.ccell.2020.04.017. PMID:32531268

48. Griessinger E, Anjos-Afonso F, Pizzitola I, Rouault-Pierre K, Vargaftig J, Taussig D, Gribben J, Lassailly F, Bonnet D. A niche-like culture system allowing the maintenance of primary human acute myeloid leukemia-initiating cells: a new tool to decipher their chemoresistance and self-renewal mechanisms. Stem Cells Transl Med. 2014; 3:520-29. https://doi.org/10.5966/sctm.2013-0166. PMID:24493855

49. Tlsty TD. Stromal cells can contribute oncogenic signals. Semin Cancer Biol. 2001; 11:97-104. https://doi. org/10.1006/scbi.2000.0361. PMID:11322829

50. Duval K, Grover H, Han LH, Mou Y, Pegoraro AF, Fredberg J, Chen Z. Modeling Physiological Events in 2D vs. 3D Cell Culture. Physiology. 2017; 32:266-77. https://doi. org/10.1152/physiol.00036.2016. PMID:28615311

51. Kunz-Schughart LA, Freyer JP, Hofstaedter F, Ebner R. The use of 3-D cultures for high-throughput screening: the multicellular spheroid model. J Biomol Screen. 2004; 9:273-85. https://doi.org/10.1177/1087057104265040. PMID:15191644

52. Ravi M, Ramesh A, Pattabhi A. Contributions of 3D Cell Cultures for Cancer Research. J Cell Physiol. 2017; 232:2679-97. https://doi.org/10.1002/jep.25664. PMID:27791270

53. Panoskaltsis N. Dendritic cells in MDS and AML--cause, effect or solution to the immune pathogenesis of disease? Leukemia. 2005; 19:354-57. https://doi.org/10.1038/ sj.leu.2403634. PMID:15674424
54. Panoskaltsis N, Reid CD, Knight SC. Quantification and cytokine production of circulating lymphoid and myeloid cells in acute myelogenous leukaemia. Leukemia. 2003; 17:716-30. https://doi.org/10.1038/sj.leu.2402835. PMID: 12682629

55. Bhatia R, McGlave PB, Dewald GW, Blazar BR, Verfaillie CM. Abnormal function of the bone marrow microenvironment in chronic myelogenous leukemia: role of malignant stromal macrophages. Blood. 1995; 85:3636-45. https://doi.org/10.1182/blood.V85.12.3636. bloodjournal85123636. PMID:7780147

56. Blanco TM, Mantalaris A, Bismarck A, Panoskaltsis N. The development of a three-dimensional scaffold for ex vivo biomimicry of human acute myeloid leukaemia. Biomaterials. 2010; 31:2243-51. https://doi.org/10.1016/j. biomaterials.2009.11.094. PMID:20015543

57. Jiang H, Sugimoto K, Sawada H, Takashita E, Tohma M, Gonda H, Mori KJ. Mutual education between hematopoietic cells and bone marrow stromal cells through direct cell-to-cell contact: factors that determine the growth of bone marrow stroma-dependent leukemic (HB-1) cells. Blood. 1998; 92:834-41. https://doi.org/10.1182/blood. V92.3.834. PMID:9680351

58. Haycock JW. 3D cell culture: a review of current approaches and techniques. Methods Mol Biol. 2011; 695:1-15. https:// doi.org/10.1007/978-1-60761-984-0_1. PMID:21042962

59. Pampaloni F, Reynaud EG, Stelzer EH. The third dimension bridges the gap between cell culture and live tissue. Nat Rev Mol Cell Biol. 2007; 8:839-45. https://doi.org/10.1038/ nrm2236. PMID: 17684528

60. Hoarau-Vechot J, Rafii A, Touboul C, Pasquier J. Halfway between 2D and Animal Models: Are 3D Cultures the Ideal Tool to Study Cancer-Microenvironment Interactions? Int J Mol Sci. 2018; 19:181. https://doi.org/10.3390/ ijms19010181. PMID:29346265

61. Aljitawi OS, Li D, Xiao Y, Zhang D, Ramachandran K, Stehno-Bittel L, Van Veldhuizen P, Lin TL, Kambhampati S, Garimella R. A novel three-dimensional stromal-based model for in vitro chemotherapy sensitivity testing of leukemia cells. Leuk Lymphoma. 2014; 55:378-91. https:// doi.org/10.3109/10428194.2013.793323. PMID:23566162

62. Smalley KS, Lioni M, Herlyn M. Life isn't flat: taking cancer biology to the next dimension. In Vitro Cell Dev Biol Anim. 2006; 42:242-47. https://doi.org/10.1290/0604027.1. PMID:17163781

63. Bhattacharya S, Calar K, de la Puente P. Mimicking tumor hypoxia and tumor-immune interactions employing threedimensional in vitro models. J Exp Clin Cancer Res. 2020; 39:75. https://doi.org/10.1186/s13046-020-01583-1. PMID:32357910

64. Birgersdotter A, Sandberg R, Ernberg I. Gene expression perturbation in vitro--a growing case for three-dimensional (3D) culture systems. Semin Cancer Biol. 2005; 15:40512. https://doi.org/10.1016/j.semcancer.2005.06.009. PMID:16055341 
65. Adjei IM, Blanka S. Modulation of the tumor microenvironment for cancer treatment: a biomaterials approach. J Funct Biomater. 2015; 6:81-103. https://doi. org/10.3390/jfb6010081. PMID:25695337

66. Fitzgerald AA, Li E, Weiner LM. 3D Culture Systems for Exploring Cancer Immunology. Cancers. 2020; 13. https:// doi.org/10.3390/cancers 13010056. PMID:33379189

67. Lv D, Hu Z, Lu L, Lu H, Xu X. Three-dimensional cell culture: A powerful tool in tumor research and drug discovery. Oncol Lett. 2017; 14:6999-7010. https://doi. org/10.3892/ol.2017.7134. PMID:29344128

68. Cukierman E, Pankov R, Stevens DR, Yamada KM. Taking cell-matrix adhesions to the third dimension. Science. 2001; 294:1708-12. https://doi.org/10.1126/science.1064829. PMID:11721053

69. Lukashev ME, Werb Z. ECM signalling: orchestrating cell behaviour and misbehaviour. Trends Cell Biol. 1998; 8:437-41. https://doi.org/10.1016/s0962-8924(98)01362-2. PMID:9854310

70. Jensen $C$, Teng Y. Is It Time to Start Transitioning From 2D to 3D Cell Culture? Front Mol Biosci. 2020; 7:33. https:// doi.org/10.3389/fmolb.2020.00033. PMID:32211418

71. Kim JB. Three-dimensional tissue culture models in cancer biology. Semin Cancer Biol. 2005; 15:365-77. https://doi. org/10.1016/j.semcancer.2005.05.002. PMID:15975824

72. Langhans SA. Three-Dimensional in Vitro Cell Culture Models in Drug Discovery and Drug Repositioning. Front Pharmacol. 2018; 9:6. https://doi.org/10.3389/ fphar.2018.00006. PMID:29410625

73. Stadler M, Walter S, Walzl A, Kramer N, Unger C, Scherzer M, Unterleuthner D, Hengstschlager M, Krupitza G, Dolznig H. Increased complexity in carcinomas: Analyzing and modeling the interaction of human cancer cells with their microenvironment. Semin Cancer Biol. 2015; 35:10724. https://doi.org/10.1016/j.semcancer.2015.08.007. PMID:26320002

74. Friedrich J, Seidel C, Ebner R, Kunz-Schughart LA. Spheroid-based drug screen: considerations and practical approach. Nat Protoc. 2009; 4:309-24. https://doi. org/10.1038/nprot.2008.226. PMID:19214182
75. Kutschka I, Chen IY, Kofidis T, Arai T, von Degenfeld G, Sheikh AY, Hendry SL, Pearl J, Hoyt G, Sista R, Yang PC, Blau HM, Gambhir SS, et al. Collagen matrices enhance survival of transplanted cardiomyoblasts and contribute to functional improvement of ischemic rat hearts. Circulation. 2006; 114:I167-73. https://doi.org/10.1161/ CIRCULATIONAHA.105.001297. PMID:16820568

76. Schleiss C, Ilias W, Tahar O, Guler Y, Miguet L, MayeurRousse C, Mauvieux L, Fornecker LM, Toussaint E, Herbrecht R, Bertrand F, Maumy-Bertrand M, Martin T, et al. BCR-associated factors driving chronic lymphocytic leukemia cells proliferation ex vivo. Sci Rep. 2019; 9:701. https://doi. org/10.1038/s41598-018-36853-8. PMID:30679590

77. Lotem J, Ben-Nun A, Sachs L. Regulation of in-vivo differentiation of myeloid leukemic cells by antigen-specific helper T lymphocytes. Leuk Res. 1986; 10:1165-68. https:// doi.org/10.1016/0145-2126(86)90233-x. PMID:2430146

78. Weiss B, Sachs L. Indirect induction of differentiation in myeloid leukemic cells by lipid A. Proc Natl Acad Sci U S A. 1978; 75:1374-78. https://doi.org/10.1073/ pnas.75.3.1374. PMID:274726

79. $\mathrm{Xu} \mathrm{H}$, Muise ES, Javaid S, Chen L, Cristescu R, Mansueto MS, Follmer N, Cho J, Kerr K, Altura R, Machacek M, Nicholson B, Addona $\mathrm{G}$, et al. Identification of predictive genetic signatures of Cytarabine responsiveness using a 3D acute myeloid leukaemia model. J Cell Mol Med. 2019; 23:7063-77. https://doi.org/10.1111/jcmm.14608. PMID:31449347

80. Cartledge Wolf DM, Langhans SA. Moving Myeloid Leukemia Drug Discovery Into the Third Dimension. Front Pediatr. 2019; 7:314. https://doi.org/10.3389/ fped.2019.00314. PMID:31417884

81. Zeng Z, Liu W, Tsao T, Qiu Y, Zhao Y, Samudio I, Sarbassov DD, Kornblau SM, Baggerly KA, Kantarjian HM, Konopleva M, Andreeff M. High-throughput profiling of signaling networks identifies mechanism-based combination therapy to eliminate microenvironmental resistance in acute myeloid leukemia. Haematologica. 2017; 102:1537-48. https://doi. org/10.3324/haematol.2016.162230. PMID:28659338 